\title{
Biosynthesis of biodegradable polymer by a potent soil bacterium from a stress-prone environment
}

\author{
Ningthoujam Chandani ${ }^{1}$, Pranab Behari Mazumder ${ }^{1 *}$, Amitabh Bhattacharjee ${ }^{2}$ \\ ${ }^{1}$ Department of Biotechnology, Assam University, Silchar, Assam, India, ${ }^{2}$ Department of Microbiology, Assam University, Silchar, Assam, India.
}

\begin{tabular}{|c|c|}
\hline ARTICLE INFO & ABSTRACT \\
\hline $\begin{array}{l}\text { Article history: } \\
\text { Received on: November 13, } 2017 \\
\text { Accepted on: December 21, } 2017 \\
\text { Available online: February } 17,2018\end{array}$ & $\begin{array}{l}\text { Polyhydroxybutyrate (PHB), produced by many microorganisms during stress condition, is an eco-friendly } \\
\text { biodegradable polymer which can completely replace the petroleum-based commercial plastics. The study was aimed } \\
\text { to screen a potent PHB-producing bacterium from municipal dumpsite areas and to analyze the effects of nutritional } \\
\text { and environmental factors to enhance production of PHB. Acinetobacter sp. K3 was a potent PHB-producing soil }\end{array}$ \\
\hline $\begin{array}{l}\text { Key words: } \\
\text { Acinetobacter, } \\
\text { Biodegradable polymer, } \\
\text { Polyhydroxybutyrate, } \\
\text { Polymerase chain reaction, } \\
\text { 16S rDNA, } \\
\text { Sequencing. }\end{array}$ & $\begin{array}{l}\text { bacterium identified by morphological, biochemical, and molecular techniques. The } 16 \mathrm{~S} \mathrm{rDNA} \text { nucleotide sequence } \\
\text { of the bacterium was assigned the accession number: KT907046 in NCBI database. Effects of different carbon, } \\
\text { nitrogen, } \mathrm{pH} \text {, and temperatures on PHB production were analyzed to enhance its product yield. It grows at the rate } \\
\text { of } 0.105 \mathrm{~g} / \mathrm{h} / \mathrm{L} \text { and PHB production achieved up to } 4.8 \mathrm{~g} / \mathrm{L} \text { from } 6.04 \mathrm{~g} / \mathrm{L} \text { dry cell weight (DCW) and PHB contents } \\
\text { amount to } 79.4 \% \mathrm{w} / \mathrm{w} \text { of total DCW. The above accumulated PHB was obtained at } \mathrm{pH} 8 \text {, temperature } 40^{\circ} \mathrm{C} \text {, mannitol, } \\
\text { and urea used as carbon and nitrogen sources, respectively. Further, } p h b A \text {, phbB, and } p h b C \text { genes responsible for } \\
\text { PHB production were amplified which confirms the presence of PHB using the gene-specific primers by polymerase } \\
\text { chain reaction technique. This new strain could be used for further industrial production of biopolymer. }\end{array}$ \\
\hline
\end{tabular}

\section{INTRODUCTION}

Polyhydroxyalkanoates (PHAs) and their derivatives are microbial biopolymer which serves as an alternative means to the existing petroleum-based plastics as they can be diminished from the environment in an eco-friendly manner. Almost 150 constituents of PHAs have been identified, and among them, poly-3-hydroxybutyric acid (polyhydroxybutyrate [PHB]) is the principal constituent widely produced intracellular by many bacteria [1]. Nowadays, PHB is gaining much concern as it has similar properties to that of petroleumbased polypropylene [2]. Due to their biodegradability property, researchers have eyed on this biopolymer from decades. However, due to its high cost of production that is mainly attributed to the cost of the carbon source and polymer recovery, its widespread use as commodity plastic has been restricted [3]. In PHB production, $40-48 \%$ of the total production costs go to the raw materials where carbon source accounts for $70-80 \%$ of the total production cost. Therefore, using suitable cultural parameters to optimize its production is the need of the hour to reduce its overall production cost. Investigating a proper and suitable medium for maximum production of PHB is of critically

\footnotetext{
*Corresponding Author:

Pranab Behari Mazumder,

Department of Biotechnology, Assam University,

Silchar, Assam, India.

E-mail:pbmazumder65@gmail.com
}

important from an industrial point of view as the medium components significantly affect the product yield.

Moreover, the burning issues of global environment and solid waste management have also created lots of concern toward the development of biodegradable polymers. Besides solving the environmental problems, PHB can be effectively used in the field of medical science owing to its biocompatibility and biodegradability characteristics. It has been reported that the main advantage of using PHB in medical field is their biocompatibility and the degradation product, 3-hydroxybutyric acid is normally present in the human blood at concentrations of $1.3 \mathrm{mmol} / \mathrm{L}$ [4]. Furthermore, because of biodegradability, PHB fibers got thinner as time proceeded when used to suture wounds in mouse [5]. PHB can also be converted into nanoparticles, which can help to deliver drugs to all the body parts including the smallest capillaries of diameter 5-6 $\mathrm{mm}$ [6].

A large number of bacteria have the capability to produce this polymer in response to unfavorable growth conditions when a carbon source is readily available [7,8]. Alcaligenes, Azotobacter, Bacillus, Nocardia, Pseudomonas, and Rhizobium produce PHB as energy reserves [9]. Alcaligenes eutrophus is the most widely explored organism for PHB production as it is easy to grow, it accumulates large amount of PHB (up to $80 \%$ of dry cell weight [DCW]) in a simple medium, and its physiology and biochemistry leading to PHB synthesis are best understood [10]. Over 250 different types of bacteria have been reported as natural PHA producers [11]. In addition to natural 
producers, genetically modified organisms are also used for industrial production of PHA [12,13]. Although a lot of bacteria have identified as PHB producers, still there is a gap in discovering a more potential bacterium that could produce PHB very efficiently in an optimized medium.

PHB biosynthesis involves three important enzymatic steps, and for this, the starting material is acetyl-coenzyme A (acetyl-CoA). Two acetyl-CoA molecules undergo reversible condensation reaction into acetoacetyl-CoA which is catalyzed by $\beta$-ketothiolase (encoded by $p h b A$ ). Anotherenzyme, NADPH-dependentacetoacetyl-CoAreductase (encoded by $p h b B$ ) reduces acetoacetyl-CoA into 3-hydroxybutyryl$\mathrm{CoA}$, and finally, polymerization of 3-hydroxybutyryl-CoA monomers by PHB synthase (encoded by $p h b C$ ) produces the polymer PHB [14].

In this report, an attempt was made to screen a potent PHB-producing bacterium from the soil samples of a stress-prone environment (municipal waste areas) and to analyze the effects of nutritional and environmental cultural parameters to enhance the production of PHB. This may help to reduce its cost of production in industrial point of context.

\section{MATERIALS AND METHODS}

\subsection{Isolation, Screening, and Characterization of PHB- Producing Bacteria}

The bacterium was isolated from the soil samples collected from municipal waste areas of Karimganj region of Southern Assam, India. For screening the PHB producing capability of the isolates, the pure cultures were grown in basally defined M9 medium (DM9 medium) and stained with Sudan Black B stain. The bacterial growth was evaluated by measuring the $\mathrm{OD}_{600}$ in UV-Vis spectrophotometer (Spectrascan UV 2600). Further, the morphological and biochemical properties of the bacterium were investigated according to Bergey's manual of determinative bacteriology [15]. For molecular characterization of the bacteria, the genomic DNA was extracted using HiPurA ${ }^{\mathrm{TM}}$ Bacterial Genomic DNA Extraction Kit and nearly full-length 16S rDNA sequences were amplified by polymerase chain reaction (PCR) using primers $27 \mathrm{~F}$ and 1492R [16]. PCR amplifications were carried out with the following temperature profile: $5 \mathrm{~min}$ at $95^{\circ} \mathrm{C}, 30$ cycles of denaturation $\left(60 \mathrm{~s}\right.$ at $\left.94^{\circ} \mathrm{C}\right)$, annealing $\left(60 \mathrm{~s}\right.$ at $\left.55^{\circ} \mathrm{C}\right)$, extension $\left(2 \mathrm{~min}\right.$ at $72^{\circ} \mathrm{C}$ ), and a final extension for $7 \mathrm{~min}$ at $72^{\circ} \mathrm{C}$. Amplified products were separated on $1 \%$ agarose gel and observed with a UV transilluminator and documented with Gel Doc XR software (Biorad). The amplification product was purified using Genejet Gel Extraction PCR Purification kit according to the manufacturer's instruction. The purified PCR product was sequenced by ABI 3500 Genetic Analyzer. The 16S rDNA gene sequence analysis was carried out using NCBIBLAST (National Centre for Biotechnology Information http://www. ncbi.nml.nih.gov) program. The sequences were aligned and the phylogenetic tree was constructed using the neighbor-joining method using MEGA 4.1.

\subsection{Seed Culture Preparation}

To $5 \mathrm{~mL}$ of the sterile nutrient broth containing (\%): Peptone, 0.5 ; beef extract, 0.3 ; and sodium chloride, 0.5 , one loopful of the bacterial stock culture was inoculated from the slant culture and incubated for $24 \mathrm{~h}$ at $30^{\circ} \mathrm{C}$ and $160 \mathrm{rpm}$. After incubation, $1 \%(\mathrm{v} / \mathrm{v})$ of the bacterial culture was transferred to $50 \mathrm{~mL}$ sterile nutrient broth and again incubated in rotary shaker under the condition of growth at $30^{\circ} \mathrm{C}$ for $18 \mathrm{~h}$.

\subsection{Microscopic Detection of PHB Granules}

PHB production was carried out on a rotary shaker at $150 \mathrm{rpm}$ using $50 \mathrm{~mL}$ of DM9 medium containing $4 \mathrm{~g} / \mathrm{L}$ glucose, $1 \mathrm{~g} / \mathrm{L} \mathrm{NH}_{4} \mathrm{Cl}, 7 \mathrm{~g} / \mathrm{L}$ $\mathrm{Na}_{2} \mathrm{HPO}_{4} 3 \mathrm{~g} / \mathrm{L} \mathrm{NaH}_{2} \mathrm{PO}_{4}, 10 \mathrm{~mL} 0.01 \mathrm{M} \mathrm{CaCl}_{2}$, and $10 \mathrm{~mL} 0.1 \mathrm{M}$ $\mathrm{MgSO}_{4} \cdot 7 \mathrm{H}_{2} 0$. The medium containing flask was autoclaved at 15 psi for $30 \mathrm{~min}$, cooled and then, $1 \%(\mathrm{v} / \mathrm{v})$ of $18 \mathrm{~h}$ old culture was inoculated and incubated at $37^{\circ} \mathrm{C}$ for $48 \mathrm{~h}$. The contents of the flask were then centrifuged at $8000 \mathrm{rpm}$ for $10 \mathrm{~min}$ at $4^{\circ} \mathrm{C}$, and the cell pellets were stained with Sudan Black B stain and observed under oil immersion microscope (Nikon Eclipse E200).

\subsection{Production and Extraction of $\mathrm{PHB}$}

Hypochlorite method with slight modification [17] was used for the extraction of PHB from Acinetobacter sp. K3. For this, the bacterium was grown in $50 \mathrm{~mL}$ of DM9 medium and incubated at $37^{\circ} \mathrm{C}$ for $48 \mathrm{~h}$ on scientific rotary shaker at $160 \mathrm{rpm} .10 \mathrm{~mL}$ of the cell suspension was centrifuged at $6000 \mathrm{rpm}$ for $10 \mathrm{~min}$ at $4^{\circ} \mathrm{C}$. The cell pellet was washed with $10 \mathrm{~mL}$ saline and was recentrifuged to get the pellet. Cell pellet was then suspended in $5 \mathrm{~mL}$ sodium hypochlorite $(4 \%$ active chlorine) and incubated at $37^{\circ} \mathrm{C}$ for $10 \mathrm{~min}$ with stirring. This extract was centrifuged at $8000 \mathrm{rpm}$ for $20 \mathrm{~min}$ at $4^{\circ} \mathrm{C}$, and the pellet of PHA was washed with $10 \mathrm{~mL}$ cold diethyl ether. The pellet was again centrifuged at $8000 \mathrm{rpm}$ at $4^{\circ} \mathrm{C}$ to get the purified PHA and was dried to constant weight at $60^{\circ} \mathrm{C}$.

\subsection{PHB Production on Different Carbon Sources, Nitrogen Sources, pH, and Temperatures}

By inoculating a single colony from nutrient agar plate into $10 \mathrm{~mL}$ Nutrient broth, and growing at $37^{\circ} \mathrm{C}$ for $16-20 \mathrm{~h}$ at $200 \mathrm{rpm}$, inoculum for PHB production was prepared. $\mathrm{PHB}$ production was monitored in DM9 medium ( $400 \mathrm{~mL}$ in $1000 \mathrm{~mL}$ conical flasks) at $37^{\circ} \mathrm{C}$ for $48 \mathrm{~h}$ in shaker at $160 \mathrm{rpm}$. To optimize the carbon source, the medium was supplemented separately with five different carbon sources (glucose, mannitol, fructose, starch, and sucrose) at a fixed concentration of $4 \mathrm{~g} / \mathrm{L}$. Among the nitrogen sources, peptone, yeast extract, tryptone, urea, and ammonium chloride were tested at fixed concentration of $1 \mathrm{~g} / \mathrm{L}$, different $\mathrm{pH}$ analyzed were $5,6,7,8$, and 9 and temperatures $25^{\circ} \mathrm{C}, 30^{\circ} \mathrm{C}, 35^{\circ} \mathrm{C}, 40^{\circ} \mathrm{C}$, and $45^{\circ} \mathrm{C}$ were experimented for PHB production.

\subsection{Evaluation of Kinetic Parameters}

Specific growth rate $(\mathrm{G})$ was determined by the formula:

$\mathrm{G}=\ln \mathrm{W} 2-\ln \mathrm{W} 1 / \mathrm{T} 2-\mathrm{T} 1 \times 100$

Where, W2 is the dry cell biomass at time T2 and W1 is the initial dry cell biomass at time $\mathrm{T} 1$. It is expressed in terms of $\mathrm{g} / \mathrm{h} / \mathrm{L}$. Content of the polymer was expressed as the ratio of PHB (P) to the biomass (X) multiplied by 100 . PHB content $=\mathrm{P} \times 100 / \mathrm{X}$. Specific PHB storage rate $(\mu)$ per unit time $(\mathrm{t})$ was given as $\mu=\mathrm{P} / \mathrm{X}$.t (g PHB produced $/ \mathrm{g}$ biomass $/ \mathrm{h})$. PHB yield at the end of the fermentation $\left(\mathrm{Y}_{\mathrm{p} / \mathrm{s}}\right)$ was calculated as the mass of PHB obtained per gram of the substrate.

\subsection{Analytical Procedure}

Cell concentration was determined by measuring the DCW. For this, $5 \mathrm{~mL}$ broth culture was centrifuged, washed with distilled water and dried at $60^{\circ} \mathrm{C}$ until the weight does not decrease further. The residual mass was defined as total DCW minus PHB weight and PHB (\%) as the percentage of the ratio of PHB to DCW. 


\subsection{Amplification of $p h b A, p h b B$, and $p h b C$ Genes}

For amplifying $p h b A$, phbB, and phbC genes in Acinetobacter sp. K3, the genomic DNA was extracted using HiPurA ${ }^{\mathrm{TM}}$ Bacterial Genomic DNA Extraction Kit and the genes were amplified by PCR using the specific primers [Table 1]. PCR amplifications were carried out with the following temperature profiles separately: phbA: Initial denaturation $\left(5 \mathrm{~min}\right.$ at $\left.94^{\circ} \mathrm{C}\right), 35$ cycles of denaturation $\left(30 \mathrm{~s}\right.$ at $\left.94^{\circ} \mathrm{C}\right)$, annealing $\left(40 \mathrm{~s}\right.$ at $\left.55^{\circ} \mathrm{C}\right)$, extension $\left(40 \mathrm{~s}\right.$ at $\left.72^{\circ} \mathrm{C}\right)$, and a final extension for $5 \mathrm{~min}$ at $72^{\circ} \mathrm{C}$; $\mathrm{phbB}$ : Initial denaturation $\left(3 \mathrm{~min}\right.$ at $\left.94^{\circ} \mathrm{C}\right), 35$ cycles of denaturation $\left(30 \mathrm{~s}\right.$ at $\left.94^{\circ} \mathrm{C}\right)$, annealing $\left(30 \mathrm{~s}\right.$ at $\left.55^{\circ} \mathrm{C}\right)$, extension $\left(30 \mathrm{~s}\right.$ at $72^{\circ} \mathrm{C}$ ), and a final extension for $7 \mathrm{~min}$ at $72^{\circ} \mathrm{C}$; and $p h b C$ : Initial denaturation $\left(5 \mathrm{~min}\right.$ at $\left.94^{\circ} \mathrm{C}\right), 35$ cycles of denaturation $(30 \mathrm{~s}$ at $\left.94^{\circ} \mathrm{C}\right)$, annealing $\left(40 \mathrm{~s}\right.$ at $\left.55^{\circ} \mathrm{C}\right)$, extension $\left(1 \mathrm{~min}\right.$ at $\left.72^{\circ} \mathrm{C}\right)$, and a final extension for $7 \mathrm{~min}$ at $72^{\circ} \mathrm{C}$.

\subsection{Statistical Analysis}

Analysis of the results obtained was done using SPSS 16.0 software, where $P<0.05$ was considered to be statistically significant.

\section{RESULTS AND DISCUSSION}

\subsection{Screening for PHB Accumulating Bacteria}

A total of 20 bacterial cultures were isolated on nutrient agar medium from the soil samples collected from municipal wastes of Karimganj region of Southern Assam. These were screened for PHB producing capability by staining with Sudan Black B stain. Stained PHB granules appeared as dark spot inside the pink colored cells after $48 \mathrm{~h}$ of growth in the production medium (DM9 medium) which was revealed by microscopic analysis [Figure 1]. Accordingly, eight among the 20 isolates were found to be PHB positive [Table 2]. These positive isolates were again inoculated in DM9 medium for estimating the amount of PHB produced. Among these isolates, $\mathrm{K} 3$ was found to be a promising producer of PHB giving a production of $2.15 \mathrm{~g} / \mathrm{L}$ PHB from $4.02 \mathrm{~g} / \mathrm{L} \mathrm{DCW}$
(53.4\% w/w of the DCW). Therefore, based on the encouraging results, isolate $\mathrm{K} 3$ was selected for further optimizing its culture conditions.

\subsection{Physiological and Biochemical Characterization of Isolate K3}

The physiological and biochemical properties of the isolate $\mathrm{K} 3$ were determined according to the methods described in "Bergey's Manual of Systematic Bacteriology" [19]. The isolate K3 is a Gram-negative, rod-shaped, non-motile, aerobic, and non-spore forming bacterium. Its colony shape is round, colony color off white, 1-2 mm colony size, have smooth surface, raised, opaque, entire, and sticky. Its optimum temperature is $30^{\circ} \mathrm{C}-40^{\circ} \mathrm{C}$ and $\mathrm{pH}$ is 6-8. This bacterium can utilize glucose, mannitol, and rhamnose but unable to utilize adonitol, arabinose, lactose, sorbitol, and sucrose. Table 3 summarizes the biochemical characteristics of the isolate $\mathrm{K} 3$.

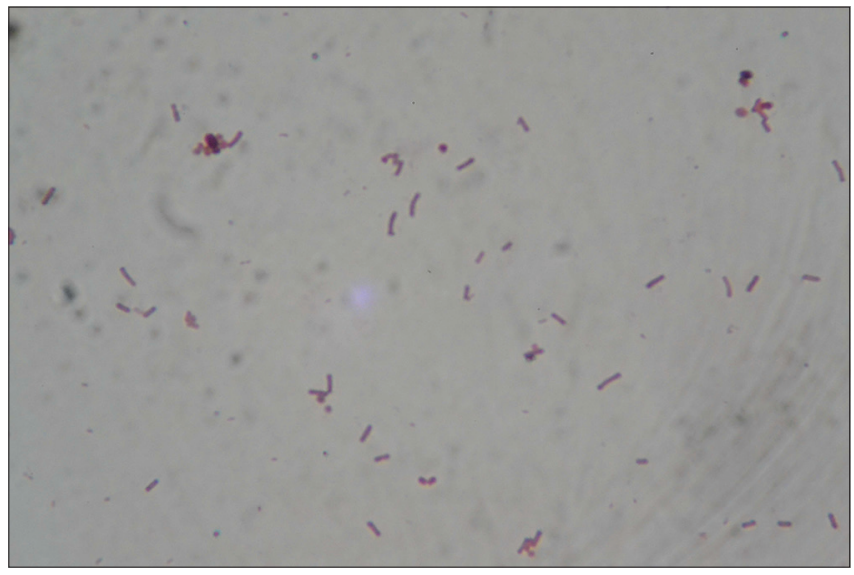

Figure 1: Cells of Acinetobacter sp. K3 stained with Sudan Black B.

Table 1: Primers used in this study.

\begin{tabular}{|c|c|c|c|c|}
\hline Name & Sequence (5'-3') & $\operatorname{Tm}\left({ }^{\circ} \mathrm{C}\right)$ & Product length & References \\
\hline$P h b A-\mathrm{F}$ & CCATGACCATCAACAAGGTG & 58 & $262 \mathrm{bp}$ & [18] \\
\hline$P h b A-\mathrm{R}$ & TATTCCTTGGCCACGTTCTC & & & \\
\hline$P h b B-\mathrm{R}$ & GTTGAACAGCGAGGTCAGGT & & & \\
\hline$P h b C-\mathrm{F}$ & СCTTCTCGCCTATGCTCTGG & 63 & 503 bp & For this study \\
\hline
\end{tabular}

Table 2: Selected eight Sudan Black B positive isolates for PHB production.

\begin{tabular}{|c|c|c|c|c|c|c|}
\hline $\begin{array}{l}\text { Sample } \\
\text { number }\end{array}$ & $\begin{array}{l}\text { Isolate } \\
\text { code }\end{array}$ & $\begin{array}{c}\text { Sudan Black B } \\
\text { test }\end{array}$ & O.D & DCW (g/L) & PHB (g/L) & $\begin{array}{c}\text { PHB } \\
\text { content }(\%)\end{array}$ \\
\hline 1 & K1 & + & 0.165 & 2.51 & 0.94 & 37.4 \\
\hline 3 & $\mathrm{~K} 2$ & + & 0.153 & 2.45 & 0.90 & 36.7 \\
\hline 4 & K4 & + & 0.150 & 2.30 & 0.87 & 37.8 \\
\hline 5 & K7 & + & 0.147 & 2.29 & 0.83 & 36.2 \\
\hline 7 & K6 & + & 0.132 & 1.68 & 0.67 & 39.8 \\
\hline 8 & K15 & + & 0.097 & 1.05 & 0.23 & 21.9 \\
\hline
\end{tabular}

DCW: Dry cell weight, PHB: Polyhydroxybutyrate. 


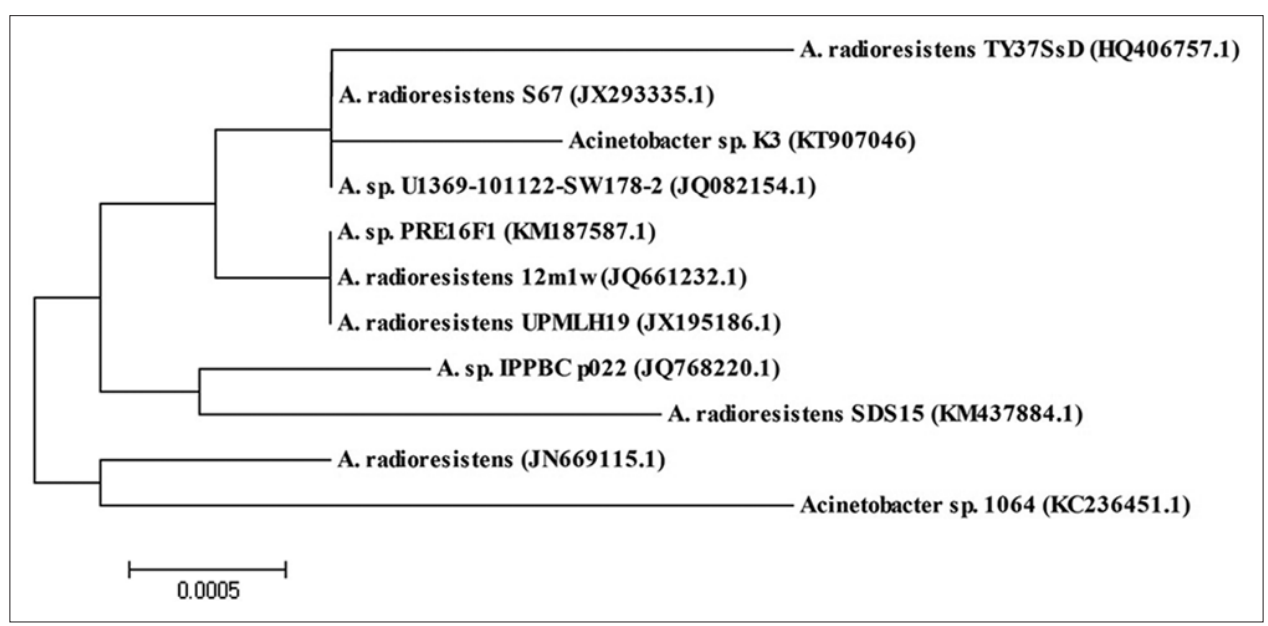

Figure 2: Phylogenetic analysis of 16S rDNA sequence of Acinetobacter sp. K3 and related strains. The tree was generated by neighbor-joining method using MEGA 4.1: Molecular Evolutionary Genetics Analysis (MEGA) software version 4.1. GenBank accession numbers are given in parentheses.

\subsection{S rDNA Gene Sequence and Phylogenetic Analysis}

The characterization of the isolate $\mathrm{K} 3$ was confirmed with $16 \mathrm{~S}$ rDNA gene sequence analysis. The almost complete sequence of 16S rDNA gene (1388 bp) of the isolate $\mathrm{K} 3$ was amplified from the genomic DNA, purified and sequenced. The gene sequence of the isolate K3 following pair-wise alignment exhibited highest (99\%) similarity with Acinetobacter sp. strain U1369-101122-SW178-2 (accession no. JQ082154.1). Therefore, the bacterium was identified as Acinetobacter sp. strain K3 and its nucleotide sequence has been deposited in NCBI database and the sequence was assigned the accession no: KT907046. The consensus sequence of the strain K3 and other related strains were aligned and the phylogenetic tree shown in Figure 2 was constructed. The evolutionary history was inferred using the neighbor-joining method [20]. The optimal tree with the sum of branch length $=0.00921500$ is shown. The tree is drawn to scale, with branch lengths in the same units as those of the evolutionary distances used to infer the phylogenetic tree. The evolutionary distances were computed using the maximum composite likelihood method [21] and are in the units of the number of base substitutions per site. Codon positions included were $1^{\text {st }}+2^{\text {nd }}+3^{\text {rd }}+$ non-coding. All positions containing gaps and missing data were eliminated from the dataset (Complete deletion option). There were a total of 1360 positions in the final dataset. Phylogenetic analyses were conducted in MEGA4 [22].

\subsection{Effects of carbon sources on PHB Production and Cell Concentration}

Growth of organism and PHB accumulation depends on specific carbon source taken up by the microorganism. Hence, carbon source is the key material in producing PHB by the microorganisms and it serves three different functions: Synthesis of biomass, energy source for biosynthesis and cell maintenance, and carbon source for PHB polymerization. Figure 3 showed that mannitol was found to be the most suitable carbon source among different carbon sources tested producing $5.81 \pm 0.01 \mathrm{~g} / \mathrm{L} \mathrm{PHB}, 71.46 \% \mathrm{DCW}$ (significance at $P<0.05$ level). Fructose and glucose are also suitable for growth and PHB accumulation after mannitol. Fructose and glucose also serves as suitable carbon sources by Bacillus mycoides [23]. It has been reported that $0.9 \% \mathrm{PHB}$ on a dry weight basis were obtained when Acinetobacter strain RA3757 was grown on valerate as carbon source [24] which is very much less when compared with our Acinetobacter $s p$. K3 when

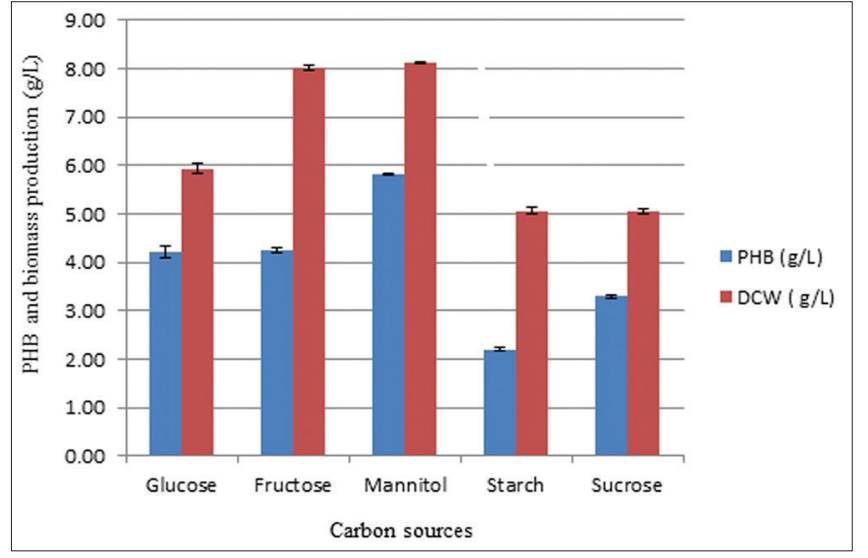

Figure 3: Effect of carbon sources on polyhydroxybutyrate (PHB) production by Acinetobacter sp. K3. PHB production was monitored in DM9 medium at $37^{\circ} \mathrm{C}$ for $48 \mathrm{~h}$ in shaker at $160 \mathrm{rpm}$.

mannitol was used as carbon source. A. eutrophus also shows high PHB yield on fructose utilization in mineral salt medium broth [8].

\subsection{Effects of Nitrogen Sources on PHB Production and Cell Concentration}

Different nitrogen sources were tried to select the best nitrogen source for PHB production by Acinetobacter sp. K3. In this study, urea was found to support maximum PHB production (significance at $P<0.05$ level) followed by tryptone and yeast extract [Figure 4]. Ammonium chloride does not support growth and PHB accumulation in this study but supports maximum PHB production from Bacillus subtilis NG05 [25]. Literature also reveals that ammonium sulfate is the best nitrogen source for different microorganisms such as A. eutrophus [26], Methylobacterium sp. [27], and Sinorhizobium fredii [28]. Therefore, the type of nitrogen source used and the type of microorganisms utilizing it are also the main factor for efficient production of PHB. This may help in industrial application as waste liquids containing $\mathrm{NH}_{4}^{+}$can be utilized for polymer synthesis.

\subsection{Effects of $\mathrm{pH}$ on PHB Production and Cell Concentration}

Proper control of $\mathrm{pH}$ is very critical as slight change in $\mathrm{pH}$ affects the metabolic process of an organism. Therefore, growth of the cell and 
PHB accumulation by Acinetobacter sp. K3 has also influenced by change in $\mathrm{pH}$ level. Here, Figure 5 indicates that PHB accumulated is maximum at $\mathrm{pH} 8$ producing $2.77 \pm 0.02 \mathrm{~g} / \mathrm{L}$ PHB (significance at $P<0.05$ level). This observation is in agreement with a previous report that $\mathrm{pH} 6.8$ to 8.0 was optimum for PHB production by A. eutrophus [29]. Further, increase in $\mathrm{pH}$ decreases the yield of PHB, which may be due to the effect on the degradative enzymes of polymer breakdown, so that PHB is used up at a rate almost equal to the rate of its synthesis. In another report, maximum PHB was obtained at pH 7-7.5 by Bacillus sphaericus NII 0838 from crude glycerol [30].

\subsection{Effects of Temperatures on PHB Production and Cell Concentration}

Maximum PHB production was recorded at $40^{\circ} \mathrm{C}$ (significance at $P<0.05$ level) after $48 \mathrm{~h}$ of growth and increase of temperature beyond $40^{\circ} \mathrm{C}$ have negative impact on PHB production [Figure 6]. This decrease in PHB at high temperatures may be due to low PHB polymerase enzyme activity [25]. This result slightly coincides with the earlier report that optimum incubation temperature for PHB production by $B$. subtilis, Bacillus pumilus, and Bacillus thuringiensis was $37^{\circ} \mathrm{C}[31,32]$.

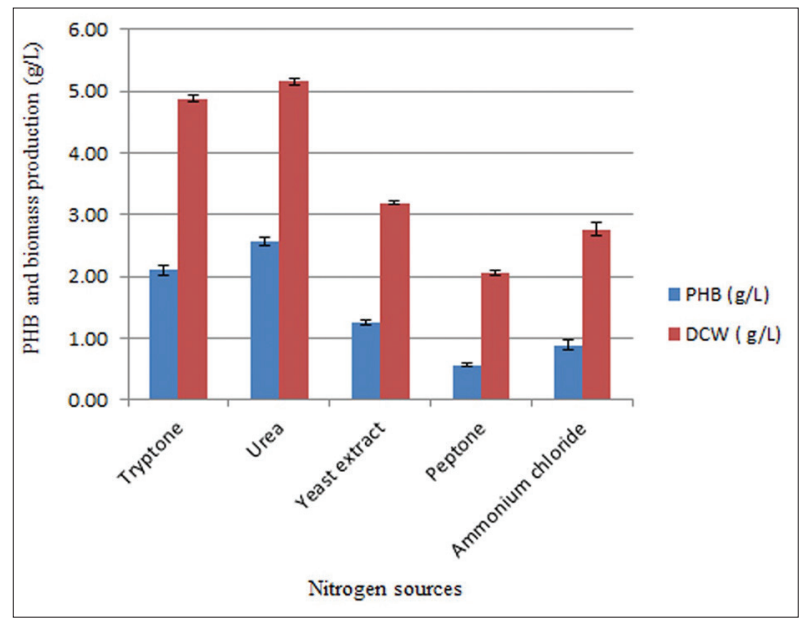

Figure 4: Effect of nitrogen sources on polyhydroxybutyrate (PHB) production by Acinetobacter sp. K3. PHB production was monitored in DM9 medium at $37^{\circ} \mathrm{C}$ for $48 \mathrm{~h}$ in shaker at $160 \mathrm{rpm}$.

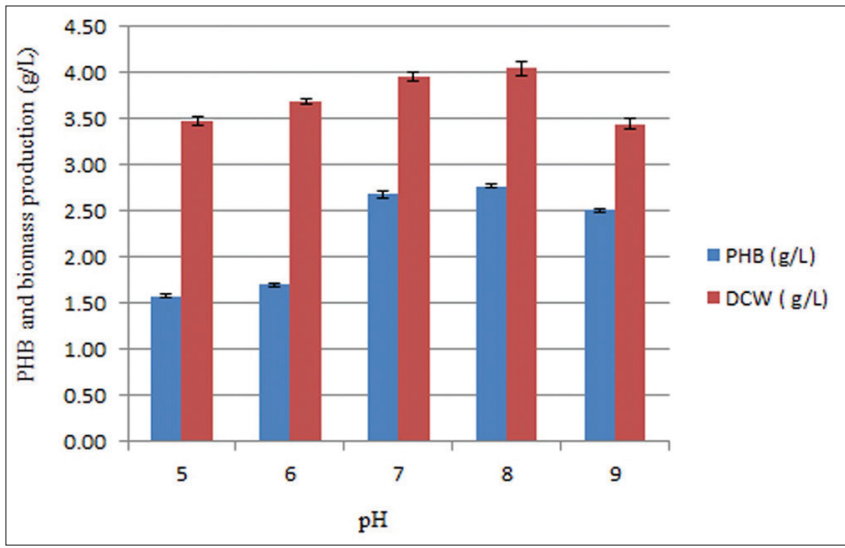

Figure 5: Effect of $\mathrm{pH}$ on polyhydroxybutyrate (PHB) production by Acinetobacter sp. K3. PHB production was monitored in DM9 medium at $37^{\circ} \mathrm{C}$ for $48 \mathrm{~h}$ in shaker at $160 \mathrm{rpm}$.

\subsection{Evaluation of Kinetic Parameters}

The kinetic parameters for the batch experiment were evaluated with respect to $\mathrm{PHB}$ and biomass production in the optimized culture medium. Table 4 summarizes that Acinetobacter sp. K3 grow at the rate of $0.105 \mathrm{~g} / \mathrm{h}$ per liter of the production medium and produces $79.4 \%$ of PHB at the rate of $0.010 \mathrm{~g} / \mathrm{g}$ of the biomass produced per hour.

\subsection{Amplification of $p h b A, p h b B$, and $p h b C$ Genes}

In this study, the PCR products of $p h b A, p h b B$, and $p h b C$ genes were amplified and separated on $1 \%$ agarose gel, observed with a UV transilluminator and documented with Gel Doc XR software (Biorad) [Figure 7]. Three fragments with the length $262 \mathrm{bp}$ for $p h b A$ gene, $174 \mathrm{bp}$ for $p h b B$ gene, and 503 bp for $p h b C$ gene have been obtained by PCR using forward and reverse primers as listed in Table 1. Amplification of these genes confirms the production of PHB by Acinetobacter $s p$. K3. This may help in studying the pathway and regulation of PHB biosynthesis in Acinetobacter sp. K3. PHB biosynthetic mechanism has been studied exhaustively in A. eutrophus [33] and Azotobacter beijerinckii [34]. However, in Acinetobacter sp., little knowledge is

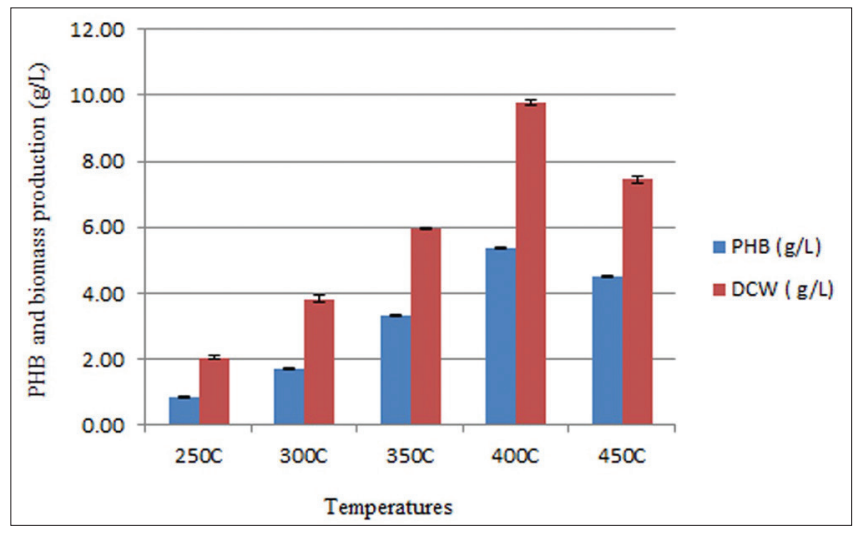

Figure 6: Effect of temperatures on polyhydroxybutyrate (PHB) production by Acinetobacter sp. K3. PHB production was monitored in DM9 medium at $37^{\circ} \mathrm{C}$ for $48 \mathrm{~h}$ in shaker at $160 \mathrm{rpm}$.

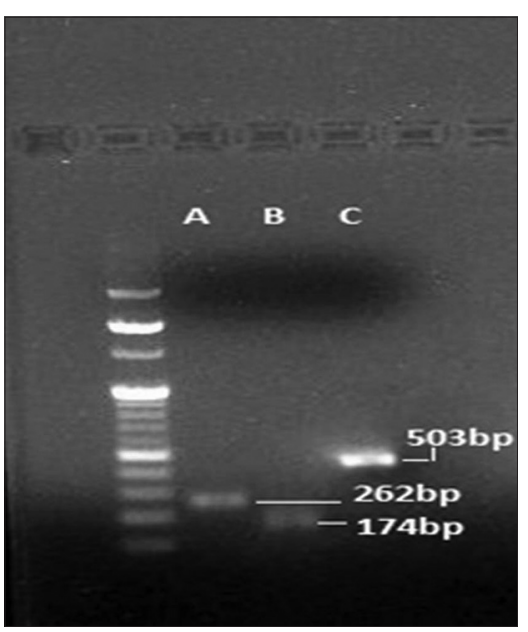

Figure 7: Amplified polymerase chain reaction products of polyhydroxybutyrate genes of Acinetobacter sp. K3. Lanes A, B, and C denotes $p h b A, p h b B$, and $p h b C$ genes, respectively, with fragment length of $262 \mathrm{bp}, 174 \mathrm{bp}$, and $503 \mathrm{bp}$, respectively. 
Table 3: Biochemical properties of Acinetobacter sp. K3.

\begin{tabular}{lc}
\multicolumn{1}{c}{ Characterization } & Sample bacteria \\
Biochemical properties & - \\
Indole & - \\
Methyl red & + \\
Voges-Proskauer & - \\
Citrate utilization & - \\
Nitrate reduction & - \\
Starch hydrolysis & + \\
Catalase & - \\
Oxidase & - \\
Urease & - \\
Gelatin liquefaction & \\
Utilization of carbohydrates & + \\
Glucose & + \\
Mannitol & + \\
Rhamnose & + \\
Adonitol & - \\
Arabinose & - \\
Lactose & - \\
Sorbitol & - \\
\hline
\end{tabular}

Table 4: Evaluated kinetic parameters of Acinetobacter sp. K3 after optimization.

\begin{tabular}{cccc}
$\begin{array}{c}\text { Specific growth } \\
\text { rate }(\mathbf{G})\end{array}$ & PHB contents $(\mathbf{P})$ & $\begin{array}{c}\text { PHB storage } \\
\text { rate }(\boldsymbol{\mu})\end{array}$ & $\begin{array}{c}\text { PHB } \\
\text { yield }\left(\mathbf{Y}_{\mathrm{p} / \mathrm{s}}\right)\end{array}$ \\
\hline $0.105(\mathrm{~g} / \mathrm{h} / \mathrm{L})$ & $79.4 \%$ & $0.010\left(\mathrm{~g} / \mathrm{g}_{\mathrm{x}} / \mathrm{h}\right)$ & $0.913\left(\mathrm{~g} / \mathrm{g}_{\mathrm{s}}\right)$ \\
\hline
\end{tabular}

PHB: Polyhydroxybutyrate

known about the metabolism of PHB though activities of some of the enzymes involved in PHB synthesis were studied in two strains of Acinetobacter sp. [24]. Hence, in this study, amplification of PHB genes not only confirms the production of PHB but also provides a reference to study the effect of these enzymes on PHB production in Acinetobacter sp. K3.

\section{CONCLUSION}

The present investigation reported the importance of nutritional and environmental effects on the production of PHB by an efficient soil bacterium Acinetobacter sp. K3. It grows at the rate of $0.105 \mathrm{~g} / \mathrm{h} / \mathrm{L}$ of the optimized production medium. PHB production achieved under optimized conditions of growth was found to be $4.8 \mathrm{~g} / \mathrm{L}$ from $6.04 \mathrm{~g} / \mathrm{L}$ DCW and PHB contents amount to $79.4 \% \mathrm{w} / \mathrm{w}$ of total DCW. The above $\mathrm{PHB}$ production was obtained at $\mathrm{pH} 8$, temperature $40^{\circ} \mathrm{C}$, mannitol as carbon source, and urea as nitrogen source, respectively. Furthermore, $p h b A, p h b B$, and $p h b C$ genes were successfully amplified which confirms the production of PHB by Acinetobacter sp. K3. Production of PHB by Acinetobacter sp. K3 was optimized and this experimentation carried out at laboratory scale will provide very useful information for scale-up studies of PHB production from Acinetobacter sp. K3 which in turn may help to reduce its cost of production. Acinetobacter sp. K3 would be a good candidate for PHB production in further studies.

\section{ACKNOWLEDGMENTS}

The authors are thankful to the Department of Biotechnology, India, for providing instruments to Microbial Molecular Biology Laboratory, Department of Biotechnology, Assam University, Silchar, Assam, India, which were used in this work.

\section{REFERENCES}

1. Cavalheiro JM, de Almeida MC, Grandfils C, Da Fonseca MM. Poly (3-hydroxybutyrate) production by Cupriavidus necator using waste glycerol. Process Biochem 2009;44:509-15.

2. Howells ER. Opportunities in biotechnology for the chemical industry. Chem Ind 1982;8:508-11.

3. Lee IY, Chang HN, Park YH. A simple method for recovery of microbial poly- $\beta$ - hydroxybutrate by alkaline solution treatment. J Microbiol Biotechnol 1995;5:238-40.

4. Zinn M, Witholt B, Egli T. Occurrence, synthesis and medical application of bacterial polyhydroxyalkanoate. Adv Drug Deliv Rev 2001;53:5-21.

5. Volova TG, Shishatskaya EI, Sevastianov VI, Efremov S, Mogilnaya O. Results of biomedical investigations of PHB and PHB/ PHV fibers. Biochem Eng 2003;16:125-33.

6. Hans ML, Lowman AM. Biodegradable nanoparticles for drug delivery and targeting. Curr Opin Solid State Mater Sci 2002;6:319-27.

7. Anderson AJ, Dawes EA. Occurrence, metabolism, metabolic role and industrial uses of bacterial polyhydroxyalkanoates. Microbiol Rev 1990;4:450-72.

8. Khanna S, Srivastava AK. Statistical media optimization studies for growth and PHB production by Ralstonia eutropha. Process Biochem 2005;40:2173-82.

9. Kato N, Konishi H, Shimao M, Sakazawa C. Production of 3-hydroxy butyric acid trimer by Bacillus megaterium B-124. J Ferment Bioeng 1992;73:246-7.

10. Kim BS, Lee SC, Lee SY, Chang HN, Chang YK, Woo SI. Production of poly (3- hydroxybutyric acid) by fed-batch culture of Alcaligenes eutrophus with glucose concentration control. Biotechnol Bioeng 1994;43:892-8.

11. Steinbukhel A. Polyhydroxyalkanoic acids. In: Byrom D, editor. Biomaterials. Novel Materials from Biological Sources. New York: Macmillan \& ICI Biological Products; 1991. p. 123-213.

12. Slater SC, Voige WH, Dennis DE. Cloning and expression in Escherichia coli of the Alcaligenes eutrophus H16 polybeta- hydroxybutyrate biosynthetic pathway. J Bacteriol 1988;170:4431-6.

13. Braunegg G, Lefebvre G, Genser KF. Polyhydroxyalkanoates, biopolyesters from renewable resources: Physiological and engineering aspects. J Biotechnol 1998;65:127-61.

14. Kadouri D, Burdman S, Jurkevitch E, Okon Y. Identification and isolation of genes involved in poly(beta-hydroxybutyrate) biosynthesis in Azospirillum brasilense and characterization of a phbC mutant. Appl Environ Microbiol 2002;68:2943-9.

15. Holt JG, Krieg NR, Sneath PH, Staley JT, Williams ST. Bergey's Manual of Determinative Bacteriology. $9^{\text {th }}$ ed. Balitomore: Williamsons and Wilkins; 1994.

16. Weisburg WG, Barns SM, Pelletier DA, Lane DJ. 16S ribosomal DNA amplification for phylogenetic study. J Bacteriol 1991;173:697-703.

17. Rawte T, Mavinkurve SA. Rapid hypochlorite method for the extraction of polyhydroxyalkanoates from bacterial cells. Indian J Exp Biol 2002;40:924-9.

18. Omidvar V, Nor Akmar AS, Marziah M, Maheran AA. A transient assay to evaluate the expression of polyhydroxybutyrate genes regulated by oil palm mesocarp-specific promoter. Plant Cell Reports 
2008;27:1451-9.

19. Kreig NR, Holt JG. Bergey's Manual of Systematic Bacteriology. Baltimore: Williams and Wilkins; 1984.

20. Saitou N, Nei M. The neighbor-joining method: A new method for reconstructing phylogenetic trees. Mol Biol Evol 1987;4:406-25.

21. Tamura K, Nei M, Kumar S. Prospects for inferring very large phylogenies by using the neighbor-joining method. Proc Natl Acad Sci U S A 2004;101:11030-5.

22. Tamura K, Dudley J, Nei M, Kumar S. MEGA4: Molecular evolutionary genetics analysis (MEGA) software version 4.0. Mol Biol Evol 2007;24:1596-9.

23. Borah B, Thakur PS, Nigam JN. The influence of nutritional and environmental conditions on the accumulation of poly-betahydroxybutyrate in bacillus mycoides RLJ B-017. J Appl Microbiol 2002;92:776-83.

24. Gavin NR, George V, John WM, Ronald CB. Production of poly$\beta$-hydroxybutyrate in Acinetobacter spp. isolated from activated sludge. Appl Microbiol Biotechnol 1992;38:734-7.

25. Gulab S, Anish K, Arpana M, Varsha G, Anita Y, Neeraj KA. Cost effective production of poly- $\beta$-hydroxybutyrate by Bacillus subtilis NG05 Using Sugar Industry Waste Water. J Polym Environ 2013;21:441-9.

26. Koutinas AA, Xu Y, Wang R, Webb C. Polyhydroxybutyrate production from a novel feedstock derived from a wheat based biorefinery. Enzyme Microb Technol 2007;40:1035-104.

27. Kim M, Baek J, Lee JK. Comparison of $\mathrm{H}_{2}$ accumulation by Rhodobacter sphaeroides KD131 and its uptake hydrogenase and PHB synthase deficient mutant. Int $\mathrm{J}$ Hydrogen Energy
2006;31:121-7.

28. Liangqi Z, Jingfan X, Tao F, Haibin W. Synthesis of poly (3-hydroxybutyrate-co-3-hydroxyoctanoate) by a Sinorhizobium fredii strain. Lett Appl Microbiol 2006;42:344-9.

29. Shivakumar S. Optimization of process parameters for maximum poly- $\beta$-hydroxybutyrate production by Bacillus thuringiensis IAM 12077. Polish J Microbiol 2009;58:149-54.

30. Sindhu R, Ammu B, Parameswaran B, Deepthi SK, Ramachandran $\mathrm{KB}$, Soccol CR, et al. Improving its thermal properties by blending with other polymers. Braz J Microbiol 2011;54:783-94.

31. Belma A, Nur YZ, Yavuz B. Determination of PHB growth quantities of certain Bacillus species isolated from soil. Turk Electron $\mathrm{J}$ Biotechnol Spec Issue 2000;24-30.

32. Hamieh A, Olama Z, Holail H. Microbial production of polyhydroxybutyrate, a biodegradable plastic using agro-industrial waste products. Glob Adv Res J Microbiol 2013;2:54-64.

33. Oeding V, Schlegel HG. Beta-ketothiolase from Hydrogenomonas eutropha $\mathrm{H} 16$ and its significance in the regulation of poly-betahydroxybutyrate metabolism. Biochem J 1973;134:239-48.

34. Senior PJ, Dawes EA. The regulation of poly- $\beta$-hydroxybutyrate metabolism in Azotobacter Beijerinckii. Biochem J 1973;134:225-38.

\section{How to cite this article:}

Chandani N, Mazumder PB, Bhattacharjee A. Biosynthesis of

biodegradable polymer by a potent soil bacterium from a stress prone

environment. J App Biol Biotech. 2018;6(2):54-60.

DOI: 10.7324/JABB.2018.60209 